\title{
ARTYKUŁY
}

Klio. Czasopismo poświęcone dziejom Polski i powszechnym

PL ISSN 1643-8191, t. 28 (1)/2014, s. 31-44

(c) (1) $\Theta$

DOI: http://dx.doi.org/10.12775/KLIO.2014.003

JACEК GZELLA

(Toruń)

\section{Wprowadzenie cenzury prewencyjnej w 1920 roku w dawnej dzielnicy pruskiej}

Proces tworzenia i wprowadzanie w życie przepisów prawnych dotyczą-
cych funkcjonowania prasy na ziemiach wcześniej pozostających pod panowaniem pruskim i na pozostałych ziemiach polskich w pierwszych latach po zakończeniu Wielkiej Wojny przebiegał w sposób odmienny. Wejście w życie traktatu wersalskiego przyznającego część ziem dawnego zaboru pruskiego państwu polskiemu dopiero z dniem 10 stycznia 1920 roku oraz utworzenie 1 sierpnia 1919 roku Ministerstwa byłej Dzielnicy Pruskiej ${ }^{1}$ wykluczało jednoczesne wprowadzenie i zastosowanie takich samych przepisów prawa regulujących zakres wolności prasy oraz normujących szczegółowy tryb nadzoru władzy państwowej nad jej działalnością w dawnym zaborze pruskim i w Rzeczypospolitej.

Na ziemiach wchodzących wcześniej w skład państwa niemieckiego obowiązywało po zakończeniu I wojny światowej ustawodawstwo niemiec-

${ }^{1}$ Szerzej o powstaniu, kompetencjach i działalności Ministerstwa zob.: A. Gulczyński, Ministerstwo bytej Dzielnicy Pruskiej (1919-1922), Poznań 1995, s. 19 i nast. 
kie. Stosowano bowiem ustawę prasową z 1874 roku ograniczającą uprawnienia władz administracyjnych w odniesieniu do konfiskat prasowych i oddającą nadzór nad prasą władzom sądowniczym, które miały kierować się w tym zakresie kodeksem karnym z 1871 roku i ustawą o postępowaniu karnym z 1877 roku, jak również ustawami szczegółowymi². Z kolei na terenach należących wcześniej do monarchii habsburskiej obowiązywały przepisy austriackiej ustawy prasowej z 1862 roku, częściowo zmienionej, np. w zakresie systemu kaucyjnego w 1894 roku oraz szczegółowa instrukcja dla władz administracyjnych z 1867 roku $^{3}$. Najbardziej skomplikowana była sytuacja panująca na ziemiach dawnego zaboru rosyjskiego, gdzie rząd Jędrzeja Moraczewskiego zniósł niemiecką cenzurę prewencyjną z okresu I wojny światowej i proklamował wolność prasy a jednocześnie nie odwołał się do rosyjskiej ustawy prasowej z 1905 roku, gdyż ta, ze względu na wprowadzenie w Królestwie Polskim stanu wyjątkowego już w 1905 roku, nie weszła w życie ${ }^{4}$.

Skomplikowana sytuacja polityczna, a przede wszystkim społeczna, której przejawem były zaburzenia społeczne, spowodowała wydanie przez Naczelnika Państwa, Józefa Piłsudskiego, 2 stycznia 1919 roku „Dekretu o wprowadzeniu stanu wyjątkowego", w myśl którego Minister Spraw Wewnętrznych lub wyznaczeni przez niego nadzwyczajni komisarze, mieli prawo w trakcie stanu wyjątkowego do

zarządzania konfiskat wszelkich wydawnictw, zagrażających bezpieczeństwu publicznemu, i zamykania na czas trwania stanu wyjątkowego drukarń służących do ich rozpowszechniania 5 .

Stan wyjątkowy, zgodnie z tym dekretem, można było wprowadzić na okres nie dłuższy niż trzy miesiące. Dekret ów został częściowo zmieniony

${ }^{2}$ M. Pietrzak, Reglamentacja wolności prasy w Polsce (1918-1939), Warszawa 1963, s. 26; J. Sobczak, Dzieje prawa prasowego na ziemiach polskich, Poznań 2009, s. 88.

M. Pietrzak, op. cit., s. 27.

4 Ibidem, s. 27-29.

5 Dekret o wprowadzeniu stanu wojennego, Dziennik Praw Państwa Polskiego 1919, nr 1, poz. 79 [dalej: DzPPP]. Dekret ten został opublikowany w: P. K. Marszałek, Polskie prawo stanów szczególnych 1918-1939. Wybór źródet, Wrocław 2004, s. 65-66. 
7 lutego 1919 roku przez dodanie sformułowania o możliwości zawieszenia czasopism w okresie obowiązywania stanu wyjątkowego ${ }^{6}$. Natomiast „Dekret o przedmiocie tymczasowych przepisów prasowych”, również z 7 lutego 1919 roku, w którym gwarantowano wolność prasy, ograniczoną tylko przepisami kodeksu karnego ${ }^{7}$, zawierał zakaz zamieszczania bez zgody władz wojskowych wiadomości dotyczących ruchu wojsk i środków obrony państwa, ogłoszeń o sprzedaży losów loteryjnych, lekarstw, a wreszcie treści pornograficznych i „przeciwnych prawu lub moralności”8.

Podobną drogą na terenie dawnego zaboru pruskiego w połowie 1919 roku poszła Naczelna Rada Ludowa (NRL), której władze wykonawcze - Komisariat - podpisały 2 czerwca „Ustawę o stanie wyjątkowym”, dopuszczającą możliwość jego wprowadzenia „tylko w razie niebezpieczeństwa grożącego krajowi z zewnątrz lub z wewnątrz"9. W wypadku ogłoszenia stanu wyjątkowego przez Komisariat, wszelkie prawa przysługujące władzom cywilnym miały zostać scedowane na władze wojskowe, mające w tej sytuacji możliwość m.in.

zaprowadzenia cenzury prewencyjnej dla wiadomości i ogłoszeń w sprawach wojskowych, zawieszanie prasy periodycznej oraz wszelkich publikacji, dalej zamykanie drukarń, służących do rozpowszechniania wspomnianych publikacji.

${ }^{6}$ Dekret o częściowej zmianie dekretu z dn. 2 stycznia 1919 r. o wprowadzeniu stanu wyjątkowego, DzPPP 1919, nr 14, poz. 159. Zob. też: P. K. Marszałek, Polskie prawo..., s. 79-80.

7 Rosyjski kodeks karny z 1903 r. został przywrócony dekretem Naczelnika Państwa 2 stycznia 1919 r. Zob.: Dekret w przedmiocie przywrócenia mocy obowiązującej części czwartej Kodeksu Karnego z 1903 r., DzPPP 1919, nr 1, poz. 81.

${ }^{8}$ Dekret o przedmiocie tymczasowych przepisów prasowych, DzPPP 1919, nr 14, poz. 186. Dnia 7 lutego 1919 r. wydano także Dekret o przedmiocie przepisów tymczasowych o zakładach drukarskich i składach druku; zob.: DzPPP 1919, nr 14, poz. 146.

${ }^{9}$ Ustawa o stanie wyjątkowym, Tygodnik Urzędowy Naczelnej Rady Ludowej 1919, nr 19, poz. 67 [dalej: TUNRL]; zob.: P. K. Marszałek, Polskie prawo..., s. 87-89. Na mocy tego dekretu Komisariat NRL już z dniem 2 czerwca wprowadził na całym terenie podległym jego władzy stan wyjątkowy; zob.: TUNRL 1919, nr 19, poz. 68. 
Należy podkreślić, że w dekrecie wydanym przez Komisariat nadal używano sformułowania o „stanie wyjątkowym”, mimo że w Sejmie Ustawodawczym, w trakcie dyskusji nad zniesieniem stanu wyjątkowego obowiązującego w Warszawie, posłowie a także ówczesny minister spraw wewnętrznych, Stanisław Wojciechowski, dowodzili, że termin ten należy zamienić na „czas wojny”" Nowością w dekrecie NRL była możliwość wprowadzenia cenzury prewencyjnej, ograniczonej co prawda do spraw wojskowych, podobnie zresztą jak w „Dekrecie o przedmiocie tymczasowych przepisów prasowych" z 7 lutego 1919 roku.

Wspomniana dyskusja na forum Sejmu Ustawodawczego doprowadziła do wydania 25 lipca 1919 roku nowej ustawy dotyczącej zapewnienia bezpieczeństwa państwa i utrzymania porządku publicznego w czasie wojny. Wprowadzono w niej możliwość ograniczenia przez Radę Ministrów, „w czasie wojny”, na okres trzech miesięcy, niektórych praw obywatelskich, w tym dotyczących funkcjonowania prasy. W artykule drugim dopuszczano możliwość m.in. „konfiskowania i zawieszania wydawnictw i czasopism zagrażających bezpieczeństwu Państwa lub porządkowi publicznemu”"11. Porządek prawny Rzeczypospolitej zatem jednoznacznie pozwalał władzom na ingerencję w treści publikacji w czasie wojny, jednak nie określał, tak jak w ustawodawstwie obowiązującym na ziemiach dawnego zaboru pruskiego, w jaki sposób będzie się to odbywało. Przepisy tej ustawy pozwoliły zatem Radzie Ministrów wprowadzić na terenie dawnego zaboru rosyjskiego i austriackiego zarządzenia wyjątkowe, w tym i te dotyczące prasy ${ }^{12}$.

Pogarszająca się sytuacja na froncie i klęski Wojska Polskiego w walkach z Armią Czerwoną spowodowały, że po utworzeniu Rady Obrony Państwa (ROP) w dniu 1 lipca 1920 roku, rozpoczęto proces ujednoli-

10 Zob. P. K. Marszałek, Regulacje prawne stanu szczególnego zagrożenia państwa $w$ debacie parlamentarnej II Rzeczypospolitej, Czasopismo Prawno-Historyczne, t. LXII, 2010, z. 2, s. 195-196.

11 Ustawa z dnia 25 lipca 1920 r. w przedmiocie zapewnienia bezpieczeństwa Państwa i utrzymania porządku publicznego w czasie wojny, DzPPP 1919, nr 61, poz. 364; zob. P. K. Marszałek, Polskie prawo..., s. 109-111.

12 Zob. Rozporządzenie Rady Ministrów w przedmiocie upoważnienia ministra spraw wewnętrznych do wydawania na całym obszarze b. zaboru rosyjskiego zarządzeń wyjątkowych, DzPPP 1919, nr 62, poz. 367. 
cenia przepisów obowiązujących w byłej dzielnicy pruskiej i na pozostałych terenach Rzeczypospolitej. Proces ten rozpoczęto od wydania w dniu 14 lipca 1920 roku rozporządzenia ROP dotyczącego wprowadzenia na obszarze byłej dzielnicy pruskiej ustawy z 25 lipca 1919 roku o zapewnieniu bezpieczeństwa państwa i utrzymaniu porządku publicznego $\mathrm{w}$ czasie wojny. W rozporządzeniu tym pojawiła się informacja o Ministerstwie byłej Dzielnicy Pruskiej, w gestii którego miało pozostawać wcielenie w życie rozporządzenia $\mathrm{ROP}^{13}$. Już następnego dnia, 15 lipca 1920 roku, prezes Rady Ministrów, Władysław Grabski, oraz kierownik Ministerstwa byłej Dzielnicy Pruskiej, Władysław Kucharski ${ }^{14}$, na mocy ustawy z 1919 roku podpisali rozporządzenie wprowadzające na obszarze byłego zaboru pruskiego stan wyjątkowy, który miał trwać trzy miesiące, od 15 lipca do 15 października 1920 roku $^{15}$ Rozporządzeniami tymi umożliwiono zatem ministrowi byłej Dzielnicy Pruskiej, po porozumieniu z ministrem spraw wewnętrznych, konfiskowanie publikacji oraz zawieszanie wydawnictw i czasopism zagrażających bezpieczeństwu państwa i porządkowi publicznemu.

Niekorzystne zmiany na froncie wschodnim wpłynęły na wydanie przez ROP dnia 19 lipca 1920 roku zarządzenia dotyczącego „ogłaszania w czasie wojny wiadomości dotyczących wojska i spraw obrony Państwa”. Wprowadzono nim cenzurę prewencyjną na terenie całej Rzeczypospolitej, gdyż wykonanie rozporządzenia powierzono ministrowi spraw wewnętrznych oraz ministrowi byłej Dzielnicy Pruskiej. Nadzór cenzorski miały pełnić władze administracyjne w porozumieniu z władzami wojskowymi, przy

13 Rozporządzenie Rady Obrony Państwa z dnia 14 lipca 1920 r. o rozciągnięciu mocy obowiązującej ustawy z dnia 25 lipca 1919 r. (DzPPP nr 61, poz. 364) w przedmiocie zapewnienia bezpieczeństwa Państwa i utrzymania porządku publicznego w czasie wojny na obszarze byłej dzielnicy pruskiej, Dziennik Urzędowy Rzeczypospolitej Polskiej 1920, nr 58, poz. 362 [dalej: DzURP]; zob.: P. K. Marszałek, Polskie prawo..., s. 120; A. Gulczyński, op. cit., s. 41.

${ }^{14}$ Kucharski został kierownikiem Ministerstwa dnia 3 lipca 1920 r., zob.: A. Gulczyński, op. cit., s. 63.

15 Rozporządzenie Rady Ministrów z dnia 15 lipca 1920 r. w przedmiocie upoważnienia Ministra b. Dzielnicy Pruskiej do wydawania na całym obszarze b. dzielnicy pruskiej zarządzeń wyjątkowych, DzURP 1920, nr 58, poz. 364, zob.: P. K. Marszałek, Polskie prawo..., s. 121 . 
czym w Krakowie i Lwowie cenzura miała pozostać w gestii policji, w pozostałych zaś miastach obowiązki cenzorskie spoczywać miały na administracji państwowej pierwszej instancji. Ta ostatnia, w miejscowościach gdzie były siedziby urzędów prokuratorskich, po wysłuchaniu opinii prokuratora sądu okręgowego, winna „niezwłocznie rozpatrzyć i orzec o dopuszczeniu ogłoszonego artykułu i wiadomości” do druku. Obowiązek przedkładania artykułów do kontroli oraz odpowiedzialność karna za przekroczenie rozporządzenia w wypadku wydawnictw periodycznych ciążyła na redaktorze odpowiedzialnym, w odniesieniu zaś do innych wydawnictw - na zarządzającym zakładem drukarskim. Za niestosowanie się do rozporządzenia ROP przewidywano kary, w dawnym zaborze rosyjskim i austriackim - administracyjne, a w zaborze pruskim - administracyjne i sądowe. Władze administracyjne na terenie całego państwa mogły zastosować konfiskatę druku i zawiesić czasopismo. Grzywnę w wysokości 50 tysięcy marek lub karę więzienia do 6 miesięcy w dawnym zaborze rosyjskim i austriackim wymierzyć mogły władze administracyjne a w dawnym zaborze pruskim sąd. Od orzeczeń władz administracyjnych przysługiwało prawo odwołania się do instancji wyższych. Odwołanie nie wstrzymywało wykonania decyzji o konfiskacie druku i zawieszenia czasopisma ${ }^{16}$.

Dopiero w dziewięć dni później, czyli 28 lipca 1920 roku, minister spraw wewnętrznych i minister byłej Dzielnicy Pruskiej wydali rozporządzenie wykonawcze do zarządzenia Rady Obrony Państwa. Doprecyzowano w nim, komu należy przedkładać publikacje do kontroli i kto ją będzie wykonywał. Dodano, że w Warszawie, Łodzi i Lublinie zajmować się nią będą komisarze rządowi, w byłej dzielnicy pruskiej - starosta grodzki w Poznaniu oraz burmistrzowie miast powiatowych, w pozostałych zaś miejscowościach całego państwa - starostowie. Obowiązek wydania decyzji miał nadal spoczywać na organach administracyjnych pierwszej instancji, które miały je podejmować w porozumieniu z władzami wojskowymi i delegowanym przez nie przedstawicielem Dowództwa Okręgu Generalnego,

16 Rozporządzenie Rady Obrony Państwa z dnia 19 lipca 1920 r. w przedmiocie ogłaszania w czasie wojny wiadomości dotyczących wojska i spraw obrony Państwa, DzURP 1920, nr 63, poz. 416, zob.: P. K. Marszałek, Polskie prawo..., s. 131-132; M. Pietrzak, op. cit., s. 36-37. 
a w siedzibach urzędów prokuratorskich - po zasięgnięciu opinii prokuratora. W wypadku różnicy zdań w sprawie oceny publikacji między przedstawicielami władzy administracyjnej i wojskowej, sprawa miała być rozpatrywana przez instancję wyższego rzędu, aż do odpowiednich ministerstw włącznie. Stwierdzono, że do czasu wydania decyzji - a sprawy miały być rozpatrywane bez względu na porę dnia - ogłoszenie inkryminowanej wiadomości miało być zabronione. Dodano także, że władze administracyjne pierwszej instancji winny pouczyć strony o prawie zaskarżenia decyzji oraz wskazać instytucję, do której należy wnosić zażalenie w myśl obowiązujących przepisów dzielnicowych ${ }^{17}$.

Jeszcze przed wydaniem wspomnianego rozporządzenia wykonawczego obu ministrów, tj. 22 lipca, administracja państwowa w dawnej dzielnicy pruskiej podjęła działania zmierzające do wprowadzenia w życie zarządzenia ROP z 19 lipca 1920 roku. W trzy dni po ukazaniu się owego zarządzenia, starosta grodzki poznański poinformował pracowników urzędu pismem okólnym o wydanym rozporządzeniu oraz zarządził, że redakcje wydawnictw periodycznych ukazujących się w Poznaniu muszą przedkładać bezpłatnie w siedzibie starostwa, w godzinach jego urzędowania od 8.00 do 18.00, trzy egzemplarze numeru pisma, który ukazał się drukiem. Niezastosowanie się do tego zarządzenia miało grozić, zgodnie z $\$ 132$ ustawy o ogólnej administracji z 3 lipca 1883 roku, karą grzywny w wysokości do 150 marek, a w przypadku nieuiszczenia grzywny - karą 14 dni aresz$\mathrm{tu}^{18}$. Zatem mimo wskazania, że zarządzenie ROP ma być realizowane, pismem tym nie wprowadzono cenzury prewencyjnej. Nastąpiło to dopiero po rozesłaniu przez wojewodę poznańskiego, Witolda Celichowskiego, poufnego pisma z 3 sierpnia 1920 roku, skierowanego do podległych mu starostów oraz magistratu Bydgoszczy. Celichowski stwierdził w nim, że wiadomości i artykuły dotyczące wojska i spraw obrony państwa mogą być wydrukowane po uzyskaniu zgody władz administracyjnych pierwszego

${ }^{17}$ Rozporządzenie wykonawcze do rozporządzenia ROP z dn. 19 VII 1920 r. (DzU nr 63, poz. 416) w przedmiocie ogłaszania w czasie wojny wiadomości dotyczących wojska i spraw obrony państwa, DzURP 1920, nr 66, poz. 446, zob.: P. K. Marszałek, Polskie prawo..., s. 139-140.

${ }_{18}$ Archiwum Państwowe w Poznaniu [dalej: APP], Starostwo grodzkie miasta Poznania [dalej: SGmP], [Nadzór nad prasą 1920-1921], sygn. 230, [k. 1]. 
stopnia: poznańskiego starosty grodzkiego, prezydenta miasta Bydgoszczy oraz starostów powiatowych. Cenzurze prewencyjnej miały podlegać wszystkie wydawnictwa drukowane

przeznaczone do puszczenia w obieg książki, broszury, czasopisma, plakaty, kartki osobne, nuty, wizerunki, rysunki, plany i mapy odbijane sposobem mechanicznym lub chemicznym ${ }^{19}$.

Redakcje pism zostały zobowiązane do przekazywania władzom administracyjnym do zatwierdzenia artykułów i wiadomości dotyczących wojska i spraw obronny państwa, a wszystkie inne publikacje miały być dostarczone w dwóch egzemplarzach w pierwszej odbitce. Obowiązkiem przedkładania cenzurze publikacji objętych nadzorem oraz odpowiedzialność karna za przekroczenie rozporządzenia miała spoczywać: w wypadku pism periodycznych - na redaktorze odpowiedzialnym, jeśli zaś idzie o inne wydawnictwa - na osobie zarządzającej drukarnią. Zabroniono redagowania tekstów w sposób pozwalający na obejście zarządzenia, a także pozostawiania w tekście pustych miejsc. Tak samo jak w zarządzeniu ROP z 19 lipca 1920 roku, uregulowano kwestię wydawania decyzji przez władze administracyjne, wojskowe i prokuraturę. Istotny był zapis, że decyzje winny zostać wydane niezwłocznie, bez względu na porę dnia. Zgodnie z rozporządzeniem ujęto kwestię ewentualnych odwołań do instancji wyższych, o czym zainteresowani mieli być powiadamiani, jednocześnie zaznaczano, że do czasu wydania decyzji ogłoszenie wiadomości było zabronione. W stosunku do osób niestosujących się do przepisów, przewidywano kary takie same jak w zarządzeniu $\mathrm{ROP}^{20}$.

Wprowadzenie przez wojewodę cenzury prewencyjnej na terenie całego województwa poznańskiego spowodowało działania administracji niższego szczebla. Z dokumentu zachowanego w Archiwum Państwowym w Poznaniu wynika, że starosta poznański 7 sierpnia, a więc w cztery dni po wydaniu przez wojewodę Celichowskiego zarządzenia, powiadomił drukarnie - a zapewne także redakcje czasopism - o wprowadzonej cenzurze,

19 Ibidem, [k. 2]; wyraz „czasopisma” został w piśmie podkreślony.

${ }^{20}$ Ibidem, [k. 3-4]. 
jej zasadach a także o karach dla osób nieprzestrzegających obowiązującego prawa $^{21}$.

Brak szybkiej reakcji administracji niższego szczebla na zarządzenie wojewody wynikał zapewne z opieszałego działania administracji oraz braku rozeznania w schematach postępowania w sprawach, które nie zdarzyły się w Poznańskiem od marca 1848 roku. Wyjaśnienia, a także wskazówki co do sposobu postępowania zawierało niedatowane pismo okólne ministra byłej Dzielnicy Pruskiej. Minister położył w nim nacisk na konieczność nawiązania kontaktu przez władze administracyjne z władzami wojskowymi i prokuraturą. Stwierdził, że przyjmowanie do ocenzurowania publikacji

winno odbywać się w godzinach nie tamujących normalnego biegu wydawnictw codziennych, które należy ustalić w porozumieniu z przedstawicielami czasopism miejscowych

i, że przyjmowanie materiałów może następować w „godzinach pozabiurowych" a nawet nocą. Rozstrzygnął także kwestię czasu, w którym powinna nastąpić kontrola, wskazując na konieczność przeprowadzenia jej w ciągu dwunastu godzin. Ze względu na krótki termin rozpatrywania spraw, zalecił zrezygnowanie z formalności kancelaryjnych, np. zapisywania przedkładanych artykułów do dziennika podawczego. Nakazał przyjmowanie publikacji w trzech egzemplarzach, z których jeden miał być przechowywany przez urząd pierwszej instancji, drugi należało oddać zainteresowanej redakcji, a trzeci - gdy artykuł dotyczył urzędów państwowych - miał być przesłany do władz drugiej instancji. Zasada ta nie obowiązywała w przypadku innych druków, np. książek, broszur, odezw, które należało składać do akceptacji w jednym egzemplarzu, jednak po ich wydrukowaniu jeden egzemplarz miał być dostarczony do władz administracyjnych pierwszej instancji. Określił także wzór pieczątki przybijanej, gdy tekst został zaaprobowany przez cenzora oraz wzór drugiej pieczątki, gdy tak się nie stało. Zwracał przy tym uwagę, że inkryminowany tekst winien zostać wykreślony czerwonym atramentem ${ }^{22}$.

21 Ibidem, [k. 5-6].

${ }^{22}$ Ibidem, [k. 7-10]. 
Minister Kucharski we wspominanym piśmie okólnym starał się wyjaśnić, co należy rozumieć pod pojęciem spraw „dotyczących wojska i obronny kraju”. Stwierdził, że należy skonfiskować te publikacje, które kwestionują autorytet naczelnego wodza, Wojska Polskiego, osłabiają znaczenie polskiej siły militarnej, zawierają tajemnicę wojskową lub ujawniają sprawy pozostające w związku z prowadzoną wojną. Dodał także:

Krytyka poważna, obiektywna, ujęta w formę rzeczowych rozważań, oparta na wiadomościach urzędowych, która nie posiada tendencji demoralizującej i szkodzącej Państwu Polskiemu, jest dopuszczalna.

Te, z natury rzeczy niezbyt precyzyjne sformułowania, zostały jeszcze opatrzone uwagą, że władze powinny przeciwdziałać „podstępnemu redagowaniu wiadomości” zmierzającemu do obejścia zarządzenia ROP z 19 lipca 1920 roku oraz nie powinny tolerować na łamach wydawnictw periodycznych pustych miejsc ${ }^{23}$.

Pismo okólne ministra Kucharskiego, przepisane przez pracowników Urzędu Wojewódzkiego, podpisane przez wojewodę Celichowskiego, 20 sierpnia 1920 roku zostało rozesłane do wszystkich starostów. W miejscu na podanie przedmiotu sprawy, której ono dotyczyło, znalazło się sformułowanie: „Regulamin dla cenzury prewencyjnej”24.

Dzień wcześniej w Poznaniu doszło do spotkania przedstawicieli miejscowej prasy i władz wojskowych, w trakcie którego ustalono, że cenzor urzędować będzie „na razie” w godzinach od 10.00 do 14.00 , od 15.00 do 16.30 oraz od 3.00 do 4.00, a biuro cenzorskie miało się mieścić na rogu ul. Składowej i Towarowej ${ }^{25}$.

Mimo stosunkowo późnego wydania „regulaminu cenzury” oraz uzgodnienia miejsca i godzin pracy urzędników nadzoru, cenzura musiała działać już w okresie wcześniejszym, czasami nadużywając kompetencji, rozciągając swe uprawnienia niezgodnie z zarządzeniem ROP i kolejnymi aktami prawnymi. Świadczy o tym pismo wojewody Celichowskiego z 25 sierpnia 1920 roku, w którym uznał za „fałszywą” dyrektywę woje-

\footnotetext{
23 Ibidem, [k. 9].

${ }^{24}$ Ibidem, [k. 11-13].

${ }^{25}$ Ibidem, [k. 14, 15].
} 
wódzkiego Departamentu Prasy, zgodnie z którą w przypadku konfiskaty jakiegokolwiek pisma związanego z ruchem narodowym należy uzyskać aprobatę wspomnianego Departamentu na ową konfiskatę. Z tego względu zarządził:

aby starostwo kierowało się przy cenzurze prasy wyłącznie względami rzeczowymi, bez względu na to, do której partii politycznej dane pismo należy ${ }^{26}$.

Nie ulega również wątpliwości, że redaktorzy wydawnictw periodycznych także próbowali obejść przepisy rozporządzenia ROP, o czym świadczy z kolei pismo starosty grodzkiego, w którym przypominał osobom odpowiedzialnym za wydawanie prasy, że to cenzura, a nie one winny decydować o tym, co dotyczy wiadomości związanych z wojskiem i obroną państwa. Trudno zatem dziwić się, że starosta przypomniał, iż nieprzestrzeganie przepisów może pociągnąć za sobą zawieszenie wydawnictwa ${ }^{27}$. Jeden ze sposobów obejścia przepisów o cenzurze prewencyjnej polegał na zamieszczaniu wiadomości związanych z toczoną wojną w sposób pośredni, np. przez relacjonowanie przebiegu wieców i wplatanie w nie treści, które zgodnie z interpretacją cenzury były zakazane, bądź też stosowaniu metody przedruków z innych pism ${ }^{28}$. Wiadomości z wieców, czy przedruki nie odnosiły się bezpośrednio do działań zbrojnych prowadzonych na froncie, jednak koncentrowały się na ocenach postępowania naczelnych władz państwa, w tym wojskowych, co uznawano za szerzenie defetyzmu. To było powodem wydania przez ministra byłej Dzielnicy Pruskiej okólnika datowanego na 26 sierpnia 1920 roku, w którym zwracał uwagę na „liczne objawy podkopywania autorytetu rządu”. Kucharski zauważył, że krytyka rządu jest dopuszczalna

jednak niedopuszczalne jest nadawanie jej takiej formy, która musi osłabiać zaufanie społeczeństwa do Rządu, podkopując tym samym trudne zadanie, związane z obroną Państwa.

${ }^{26}$ Ibidem, [k.16].

${ }^{27}$ Ibidem, [k. 17].

${ }^{28}$ Ibidem, [k. 18]. 
Dowodził także, że postawy prezentowane w prasie mogą spowodować osłabienie morależołnierza walczącego na froncie, stąd domagał się zastosowania jak najostrzejszych środków, pozbawiających wolności „szkodników państwowych”, jednak polecił ścisłe przestrzeganie prawa, by uniknąć „wszelkich szykan i krzywd osobistych”, jak również domagał się równego traktowania przedstawicieli różnych ugrupowań politycznych, społecznych i narodowościowych ${ }^{29}$.

W pierwszych dniach września starosta poznański zawiadomił redaktorów odpowiedzialnych, że od 9 września 1920 roku należy zaprzestać omawiania kwestii tzw. armii rezerwowej, zarówno w artykułach, jak również $\mathrm{w}$ sprawozdaniach $\mathrm{z}$ wieców, czy przedrukach $\mathrm{z}$ innych tytułów prasowych. Poinformował także, że niedopuszczalna jest krytyka władz centralnych w sposób podważający ich autorytet, a tym samym osłabiająca zaufanie społeczne do urzędu oraz „podkopująca ważne zadania związane z obroną Państwa” ${ }^{30}$. Kwestia armii rezerwowej wspomniana w piśmie starosty była dla ówczesnych władz bardzo istotna, gdyż była wykorzystywana przez dziennikarzy do propagowania idei autonomii Wielkopolski oraz do prezentowania krytycznych ocen wobec poczynań najwyższych władz państwowych i wojskowych. Zakaz pisania o armii rezerwowej został cofnięty dopiero 21 października 1920 roku, a więc wtedy, gdy obowiązywało już rozporządzenie ROP z 17 września tego roku dotyczące kar za obrazę Naczelnika Państwa ${ }^{31}$.

Funkcjonowanie w kolejnych miesiącach na terenie całego państwa cenzury prewencyjnej w publikacjach dotyczących wojska i spraw obrony państwa trudno było uzasadnić ze względu na sukcesy armii polskiej na froncie wschodnim. W trakcie posiedzenia sejmu 29 października 1920 roku, przedstawiciel Komisji Konstytucyjnej zgłosił wniosek o uchylenie rozpo-

${ }^{29}$ Ibidem, [k. 19-20].

${ }^{30}$ Ibidem, [k. 21].

${ }^{31}$ Ibidem, [k. 23, 24], zob.: Rozporządzenie Rady Obrony Państwa z dnia 17 września 1920 r. w przedmiocie kar za obrazę Naczelnika Państwa, DzURP 1920, nr 91, poz. 598. Zob. też: P. K. Marszałek, Polskie prawo..., s. 158. Za obrazę Naczelnika Państwa w dawnym zaborze pruskim wprowadzono karę aresztu lub więzienia do lat trzech i grzywny do 10 tysięcy marek, lub jedną z tych kar. Szarzej o armii rezerwowej zob.: A. Gulczyński, op. cit., s. 164. 
rządzenia ROP z 19 lipca 1920 roku. Rząd, zgodnie z tym wnioskiem, miał zostać zobowiązany do zniesienia w ciągu 24 godzin cenzury prewencyjnej, skasowania i zwrotu grzywien egzekwowanych z tytułu obowiązującego rozporządzenia. Większością głosów sejm rozporządzenie uchylił ${ }^{32}$.

Uchylenie rozporządzenia ROP dotyczącego cenzury prewencyjnej spowodowało działania administracji państwowej w dawnym zaborze pruskim, zmierzające do wprowadzenia w życie uchwały parlamentu. Proces ten wydaje się bardzo rozciągnięty w czasie. Minister byłej Dzielnicy Pruskiej dopiero 8 listopada 1920 roku nakazał zniesienie cenzury prewencyjnej, a wojewoda poznański pismem z 16 listopada tego roku polecił wstrzymanie wszystkich czynności związanych z wykonywaniem cenzury prewencyjnej zaprowadzonej w myśl rozporządzenia ROP. Ponadto zarządził wstrzymanie ściągania kar nałożonych zgodnie z artykułem szóstym wspomnianego rozporządzenia Rady. Przypomniał jednocześnie starostom, że „pozostało natomiast prawo kontroli wszelkich publikacji zaraz po wyjściu ich z drukarni”33. Na dokument starosty grodzkiego poznańskiego znoszący jego zarządzenie dotyczące cenzury prewencyjnej prasa stolicy Wielkopolski musiała czekać aż do 25 listopada 1920 roku $^{34}$.

Sposób, w jaki w lipcu 1920 roku wprowadzono na ziemiach dawnego zaboru pruskiego przepisy dotyczące cenzury prewencyjnej oraz wydanie zarządzeń ją odwołujących dopiero w końcu listopada tegoż roku, musi wywoływać zdziwienie. Trudno bowiem nie zauważyć, że rozporządzenia o wprowadzeniu cenzury wydawano na poszczególnych szczeblach administracji województwa poznańskiego w odstępach trzech-czterech dni, a szczegółowe przepisy określające sposób jej wykonania pojawiły się dopiero po dwóch tygodniach. Sytuację tę można jedynie wytłumaczyć innymi zasadami funkcjonowania cenzury na tych terenach przed 1920 rokiem. Trudno natomiast w sposób jednoznaczny wskazać powody, dla których tak długo, gdyż prawie przez miesiąc, odwoływano przepisy dotyczące cenzury prewencyjnej. Wydaje się, że podstawowym powodem była reakcja

32 P. K. Marszałek, Rada Obrony Państwa z 1920 roku. Studium prawno-historyczne, Wrocław 1995, s. 120-121.

${ }^{33}$ APP, SGmP, [Nadzór...], [k. 25].

${ }^{34}$ Ibidem, [k. 26]. 
społeczeństwa wielkopolskiego na przebieg wojny polsko-sowieckiej i powstałe na tym tle dążenia separatystyczne na ziemiach dawnego zaboru pruskiego, połączone z bardzo negatywną oceną działań władz państwowych, z Józefem Piłsudskim na czele.

\section{Introduction of Preventive Censorship in 1920 in the Former Prussian Partition}

(SUMMARY)

During the restitution of the Polish Statehood in 1918, the individual provinces maintained the laws of the previous occupying powers with regard to regulating the freedom of the press and specific procedures of the oversight that state authorities had over the press activities. Since January 1919, there was an option to impose a confiscation of any publication in the part of Polish Republic, in which a martial law was in effect. This route, allowing for the introduction of preventive censorship, was used in June 1919 by the Supreme People's Council, an organization that was in power in the Wielkopolska district (of the former Prussian partition). The volatile situation at the front of the Polish-Bolshevik war prompted the Polish authorities to uniform the laws regarding preventive censorships. Subsequently, the Council of National Defense issued on July 19th, 1920 a decree introducing the preventive censorship on the territory of the Polish state. Despite the lack of respective executive directives from the Ministries of Internal Affairs and Ministry of Former Prussian Partition, the Poznań city mayor [starosta grodzki] started implementing the preventive censorship regulations already on July 22, 1920. These restrictions pertained to publications relevant to the army and matters of state defense. However, the implementation of these regulations was aborted after the Polish Parliament approved on October 29, 1920 a bill abolishing a preventive censorship. Nonetheless, the Wielkoposka district waited until November 25, 1920 when the Poznań city mayor [starosta grodzki] issued a document revoking his previous decree about preventive censorship.

Jacek Gzella

Instytut Informacji Naukowej i Bibliologii, Uniwersytet Mikołaja Kopernika jagze@umk.pl 